\title{
Natural Nuclear Radioactivity and Crystallography Composition of Camburi Sand Beach (Vitória - ES, Brazil)
}

\author{
Arthur Cavichini ${ }^{1}$ \\ E-mail: nnenas@gmail.com \\ E. F. Sperandio, M. T. D. Orlando, J. B. Depianti, V. A. Rodrigues, E. Betini \\ Universidade Federal do Espírito Santo - Centro de Ciências Exatas, Departamento de Física \\ Av. Fernando Ferrari, 514 Campus Goiabeiras - CEP 29075-910,Vitória-ES - Brazil \\ E-mail: mtdorlando@gmail.com
}

It was developed an investigation of natural nuclear activity and crystallography composition of sand clusters with natural nuclear activity deposited on Camburi beach (Vitória - ES, Brazil). Several samples have been removed from the Camburi taken into account the level of natural radioactivity. Our first observation is that the presence of these radioactivity sand clusters is no homogenous, as considering the date evolution parameter and geographical coordinates. Some samples were analyzed by SEM images and the EDS analysis of the grains had shown the presence of $\mathrm{K}^{40}, \mathrm{U}^{238}$ and $\mathrm{Th}^{232}$ as the most abundant radioactivity elements and $\mathrm{Ce}$ atomic element. Some sand samples were magnetic fractioned and produced two new samples labeled as black and white sand. All black and white samples have been analyzed by X-ray diffraction. In black sand it was found Ilmenite, Rutile W-Rich, and Silicon, and the white sand had shown Monazite-(Ce) and Uranium Phosphate, Thorium Oxide and Thorium Fluoride. In our point of view, the clusters of sand with radioactivity chemical elements present in Camburi beach change its geographical coordinates considering the weather and ocean currents influence.

XXXIV edition of the Brazilian Workshop on Nuclear Physics,

Foz de Iguaçu, Parana state, Brasil

5-10 June 2011

Speaker 


\section{Introduction}

The main environmental function of beaches is to protect the continent from direct and violent action of oceans [1], keeping the dynamic coast sedimentation balance. Beach sediment origin may be by river, from longitudinal transport or from the continental platform [2].

The Camburi beach is a beautiful bay with $6 \mathrm{~km}$ extension, localized on north of Vitória city, in Espírito Santo state. Result of a common phenomenon on east and south Brazilian coast, caused by the transport and deposit of sediments through thousands years, and is limited on south for a crystalline emerging $\left(20^{\circ} 15^{\prime} \mathrm{S} 40^{\circ} 15^{\prime} \mathrm{O}\right.$ coordinates), represented for Fato Island e Ponta Formosa (Sagrado Coração de Maria School hill) and on north by Tabualeiros salience, Barreiras formation and Tubarão Port ( $20^{\circ} 17^{\prime} \mathrm{S} 40^{\circ} 17^{\prime}$ O coordinates)[3][4][5].

Presence of black spots on beach sand, closer on spreading region, led to a more careful analysis of his compounds. Portions was collected and analyzed by radiometry counting, Scanning Electron Microscope and Electron Dispersion. The Results shown radionuclides such as uranium (U), thorium (Th) e phosphate $(\mathrm{K})$ attached on crystal's beach surface. Cerium compounds also were found on high concentrations.

\section{Methodology}

Since 2009 have been collected samples from some points of Camburi beach periodically. Camburi beach was divided in 3 regions: Iemanjá, Oficiais and Entre Piers. The collect points were chosen walking through the beach and identifying the black sands clusters (Fig. 1). To collect the samples were used pet bottles. In each incursion on beach were annotated information about the date, position (using GPS), weather, wind force, tide and distance from shoreline. Afterward, the samples were led to the lab, where were dried naturally, with no use of a furnace or an incubator.

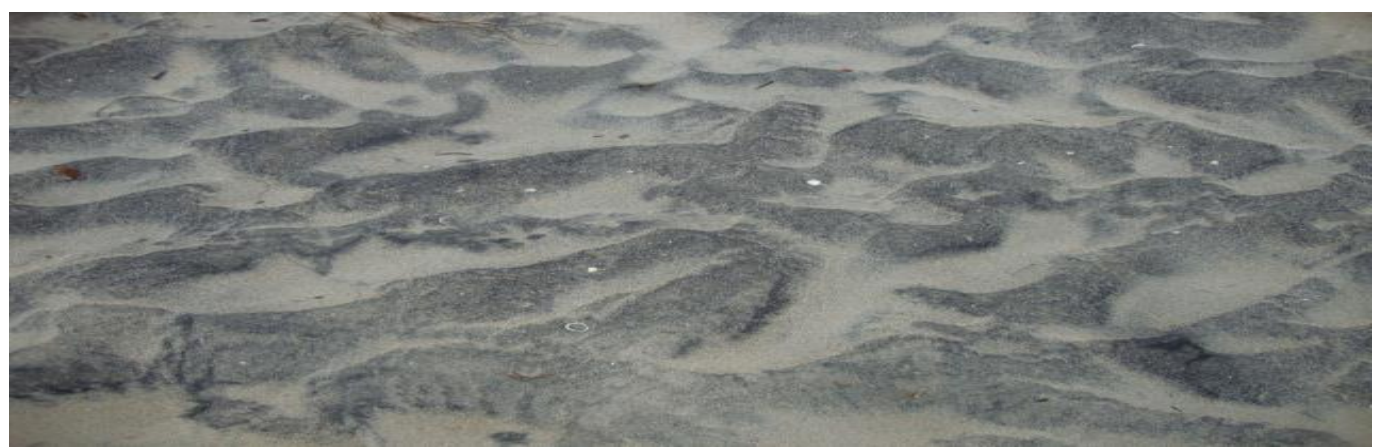

Fig. 1 - Black sand clusters presents in Camburi beach. The white shells in the sand are about $3 \mathrm{~cm}$. Personal archive.

After dried, the samples were weighed and cataloged. Also were removed manually organics materials like branches, shells, seaweeds, etc. Then the clean sands were sealed in polyethylene flasks of $400 \mathrm{ml}$ for counting.

A Geiger-Müller from PHYWER was used to measure the nuclear activity. Fifteen measures in a time of 100 s were made for each sample. Each day that was made a count, was measured the background nuclear activity of the room. 
Some samples were subjected to the X-ray, Scanning Electron Microscope (SEM) and Energy Dispersive X-ray Spectroscopy (EDS or EDX) measurements, for this they were magnetically partitioned in two new samples, labeled black and white sand.

The samples were sieved by a $20 \mu \mathrm{m}$ thin mesh to do X-ray measures. The measures were realized using Rigaku model Ultima IV, with copper tube (1.5418 $⿱$ ) ), scanning from 4.00 to 120.00 degrees with a $0.01^{\circ}$ step.

\section{Results and Discussion}

In this work was presented the results only from Iemanjá region. Was collected a total of 25 samples in a time of 30 weeks (Table 1) with $500 \mathrm{~g}$ approximated and considering time range of 30 weeks.

\subsection{Radioactivity Measurements}

Table 1 - Samples collect day, distance from Iemanjá Pier and activity count.

\begin{tabular}{|c|c|c|c|c|c|}
\hline Date & $\begin{array}{c}\text { Distance from Iemanjá } \\
\text { Pier (meters) }\end{array}$ & Count/100s & Date & $\begin{array}{c}\text { Distance from Iemanjá } \\
\text { Pier (meters) }\end{array}$ & Count/100s \\
\hline $08 / 24 / 09$ & 215.83 & 232 & $12 / 03 / 09$ & 246.67 & 55 \\
\hline $08 / 31 / 09$ & 524.17 & 48 & $12 / 17 / 09$ & 246.67 & 55 \\
\hline $09 / 07 / 09$ & 154.17 & 46 & $12 / 22 / 09$ & 339.17 & 44 \\
\hline $09 / 14 / 09$ & 277.50 & 131 & $01 / 07 / 10$ & 277.50 & 124 \\
\hline $09 / 21 / 09$ & 277.50 & 147 & $01 / 15 / 10$ & 215.83 & 86 \\
\hline $09 / 28 / 09$ & 308.33 & 103 & $02 / 05 / 10$ & 215.83 & 62 \\
\hline $10 / 08 / 09$ & 215.83 & 136 & $02 / 12 / 10$ & 246.67 & 68 \\
\hline $10 / 13 / 09$ & 370.00 & 41 & $02 / 24 / 10$ & 215.83 & 40 \\
\hline $10 / 20 / 09$ & 585.83 & 98 & $03 / 03 / 10$ & 555.00 & 51 \\
\hline $10 / 26 / 09$ & 215.83 & 81 & $03 / 08 / 10$ & 585.83 & 51 \\
\hline $11 / 07 / 09$ & 277.50 & 84 & $03 / 15 / 10$ & 308.33 & 131 \\
\hline $11 / 18 / 09$ & 339.17 & 82 & $03 / 25 / 10$ & 246.67 & 85 \\
\hline $11 / 25 / 09$ & 339.17 & 57 & & & \\
\hline
\end{tabular}

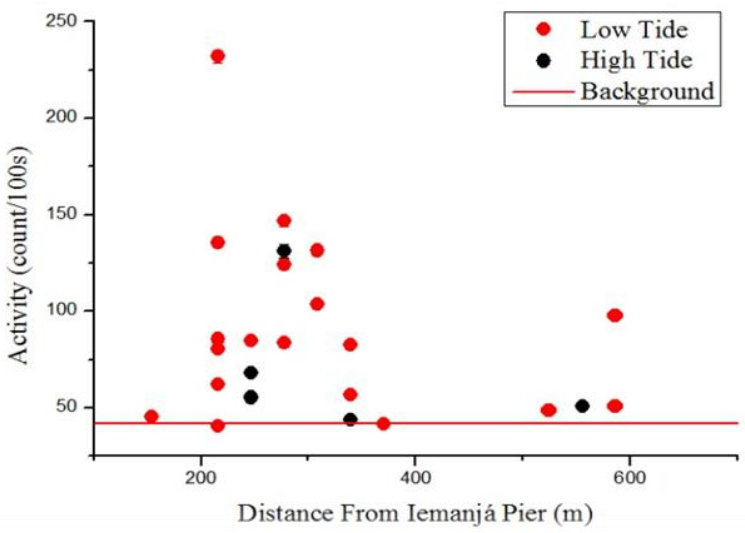

Fig. 2 - Activity concentrations of Iemanjá Region beach sand in function of the distance from Iemanjá Pier. The line is associated with the background radioactivity. 
Five samples of the same region were analyzed in time, as shown by the Fig. 3:

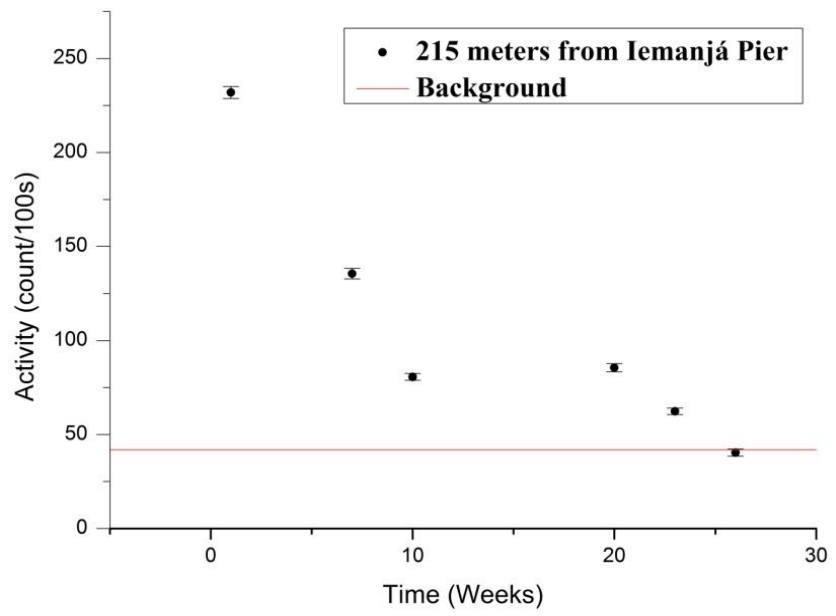

Fig. 3 - Activity of Iemanjá Region beach sand in function of time on 255 meters from Iemanjá Pier. The line had shown the background radioactivity counts.

\subsection{SEM and EDS}

To do the SEM and EDS measures, the samples were prepared with a thin conductor deposit. The results are showed below (Fig. 4 and Table 2):

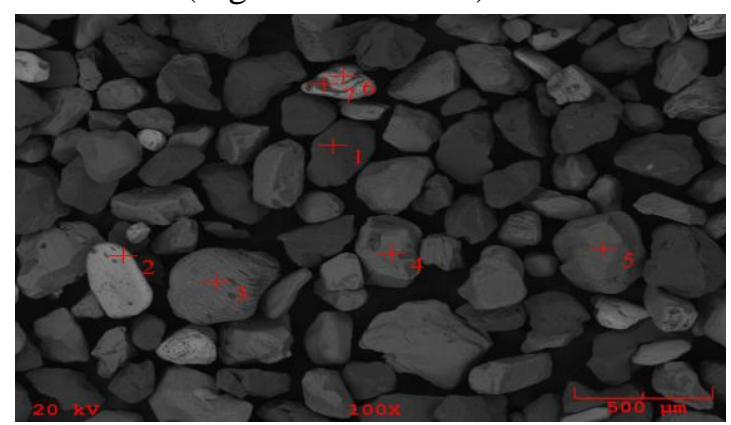

Fig. 4 - SEM image of Iemanjá \#1 (8/24/09 - 215.83 m) white sand sample.

Table 2 - EDS of region 6 from (Fig. 4) shows the presence of Cerium Phosphate. $2.0 \mathrm{kV}$, take off Angle 35.0 and Elapsed Life Time 100.0.

\begin{tabular}{|c|c|c|c|c|c|c|}
\hline Element & Line & $\begin{array}{l}\text { Intensity } \\
(\mathrm{c} / \mathrm{s})\end{array}$ & $\begin{array}{c}\text { Error } \\
2 \text {-sig }\end{array}$ & $\begin{array}{l}\text { Atomic } \\
\%\end{array}$ & Concentration & \\
\hline $\mathrm{O}$ & $\mathrm{Ka}$ & 111.460 & 2.111 & 49.475 & 17.279 & wt $\%$ \\
\hline $\mathrm{Mg}$ & $\mathrm{Ka}$ & 6.440 & 0.508 & 0.910 & 0.483 & wt $\%$ \\
\hline $\mathrm{Si}$ & $\mathrm{Ka}$ & 44.380 & 1.332 & 4.411 & 2.704 & wt $\%$ \\
\hline $\mathrm{P}$ & $\mathrm{Ka}$ & 252.840 & 3.180 & 21.385 & 14.459 & wt $\%$ \\
\hline $\mathrm{Cl}$ & $\mathrm{Ka}$ & 2.480 & 0.315 & 0.175 & 0.135 & wt $\%$ \\
\hline $\mathrm{Ca}$ & $\mathrm{Ka}$ & 18.940 & 0.870 & 1.141 & 0.998 & wt $\%$ \\
\hline $\mathrm{Fe}$ & $\mathrm{Ka}$ & 23.040 & 0.960 & 1.761 & 2.147 & wt $\%$ \\
\hline Co & $\mathrm{Ka}$ & 1.670 & 0.258 & 0.139 & 0.178 & wt $\%$ \\
\hline $\mathrm{Pd}$ & $\mathrm{La}$ & 7.740 & 0.557 & 0.627 & 1.456 & wt $\%$ \\
\hline $\mathrm{Ag}$ & $\mathrm{La}$ & 38.820 & 1.246 & 3.118 & 7.343 & wt $\%$ \\
\hline $\mathrm{La}$ & $\mathrm{La}$ & 47.780 & 1.382 & 4.357 & 13.211 & wt $\%$ \\
\hline $\mathrm{Ce}$ & $\mathrm{La}$ & 122.880 & 2.217 & 11.337 & 34.676 & wt $\%$ \\
\hline $\mathrm{W}$ & $\mathrm{La}$ & 1.490 & 0.244 & 0.263 & 1.057 & wt $\%$ \\
\hline $\mathrm{Au}$ & $\mathrm{La}$ & 3.810 & 0.390 & 0.901 & 3.875 & wt $\%$ \\
\hline
\end{tabular}




\subsection{X-Ray Diffraction Measurements}

The X-ray measures were made to determine the compounds present in Iemanjá region sand of Camburi beach. The X-ray diffraction patterns of black and white sand are presented below (Fig. 5 and Table 3):

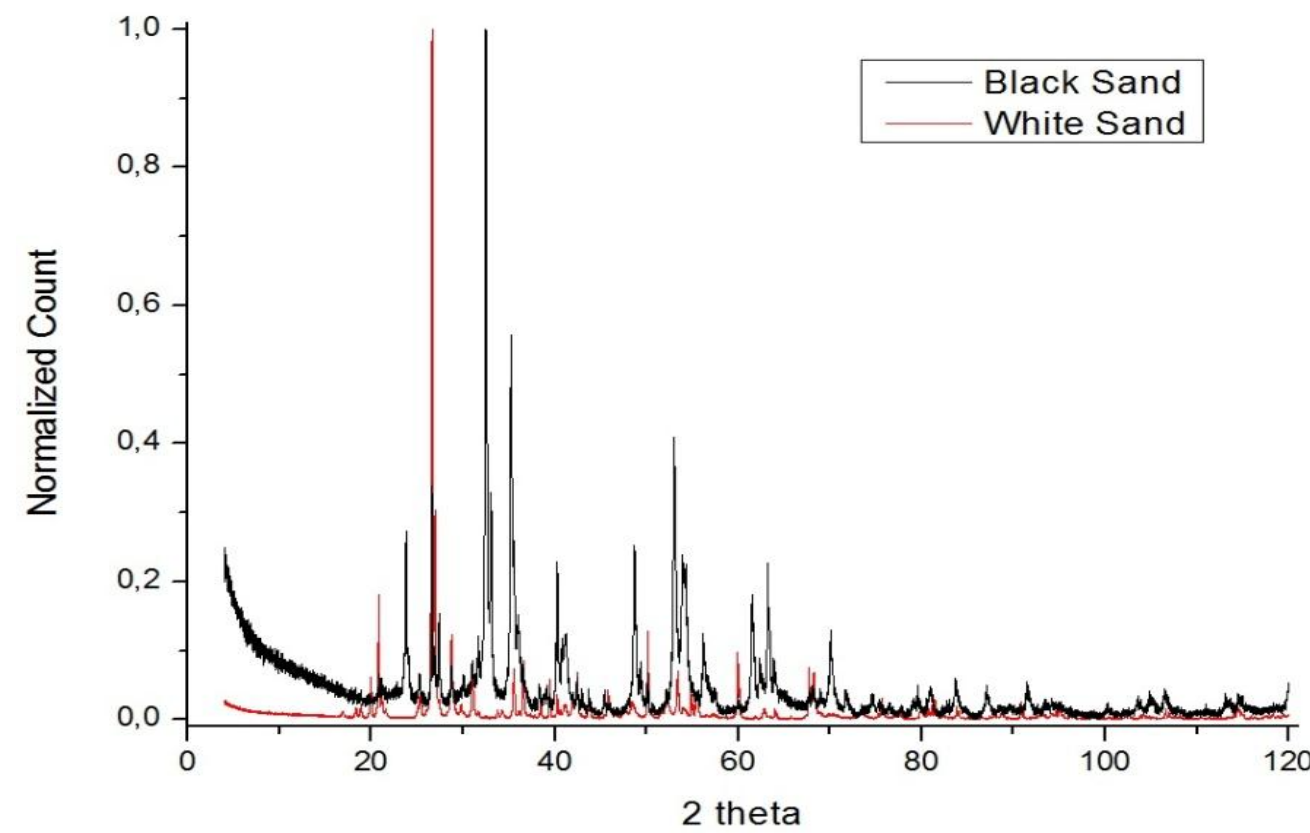

Fig. 5 - X-ray diffraction patterns of Black Sand and White Sand. 2 theta represent the scanning angle.

Table 3 - The identified phases by X-Ray measurements in black and white sand.

\begin{tabular}{|c|c|c|c|}
\hline \multirow{5}{*}{ Black Sand } & Ilmenite $\left(\mathrm{FeTiO}_{3}\right)$ & \multirow{5}{*}{ White Sand } & Monazite - $(\mathrm{Ce})\left((\mathrm{Ce}, \mathrm{La}, \mathrm{Nd}) \mathrm{PO}_{4}\right)$ \\
\hline & Iron Tin Oxide $\left(\mathrm{Fe}_{1.874} \mathrm{Sn}_{0.096} \mathrm{O}_{3}\right)$ & & $\begin{array}{l}\text { Cerium Uranium Phosphate } \\
\qquad\left(\mathrm{Ce}_{0.9} \mathrm{U}_{0.1} \mathrm{PO}_{4}\right)\end{array}$ \\
\hline & $\begin{array}{c}\text { Rutile W-Rich } \\
\left(\mathrm{Ti}_{0.0894} \mathrm{~V}_{0.069} \mathrm{Sb}_{0.014} \mathrm{~W}_{0.022} \mathrm{O}_{2}\right)\end{array}$ & & $\begin{array}{l}\text { Lanthanum Thorium Oxide } \\
\qquad\left(\mathrm{La}_{1.64} \mathrm{Th}_{2.36} \mathrm{O}_{7.18}\right)\end{array}$ \\
\hline & \multirow[b]{2}{*}{$\alpha$ Silicium Oxide $\left(\mathrm{SiO}_{2}\right)$} & & $\alpha$ Silicium Oxide $\left(\mathrm{SiO}_{2}\right)$ \\
\hline & & & $\begin{array}{l}\text { Sodium Thorium Fluoride } \\
\qquad\left(\mathrm{Na}_{3} \mathrm{Th}_{2} \mathrm{~F}_{11}\right)\end{array}$ \\
\hline
\end{tabular}

\section{Conclusion}

In our point of view, the sand found in the Camburi beach cannot be considered as a homogeneous and constant system. Our investigation has indicated that black sand is grouped in clusters that migrate on different beach regions. There exist experimental indications that these clusters may carry the most part of radioactivity chemical elements of the sand. Taking into account the fig. 3 , the activity as a time function to a fixed region indicates a reduction, which is associated with a gradual migration of the radioactivity clusters to another region. The analyses 
of the others Camburi regions data mentioned here indicated that an investigation about the oceanography, weather conditions, and another factors must be done in order to determine the migration of the clusters sand in Camburi beach.

X-ray diffraction, SEM and EDS measurements confirmed there are Thorium, Potassium and Uranium, as showed on other previous works [6][7]. However, thus EDS and X-ray measures presented high concentrations of Cerium, which was not showed previously.

This work was done taking samples periodically therewith we showed the nuclear activity found in the sand of Camburi beach is a function of several parameters.

A qualitative view was presented on this paper, and an analysis with gamma spectrometry may make clear the relation of the natural factors with the nuclear activity on time.

\section{Acknowledgments}

We would like to thank the Pos-Graduation Program in Mechanical Engineering of Universidade Federal do Espírito Santo for the SEM, EDS and X-Ray measurements and CNPQ for support our research. We also thanks to ArcelorMittal, Vale, LNLS and CAPES.

\section{References}

[1] Albino, J. Morfodinâmica e processos de sedimentação das praias da Barra e São José do Barreto, Macaé-RJ, ES. Dissertação de Mestrado. Programa de Pós- graduação em Geografia. UFRJ. 1993.

[2] Hoefel, F. G. Morfodinâmica de praias arenosas oceânicas: uma revisão bibliográfica. Editora da UNIVALI, p.21-22. 1998.

[3] COSTA, B.R. Expansão urbana da área norte de Vitória. Espírito Santo. Ed. Cultural, 1989.

[4] MARTIN, L. et al. Quaternary formations of the southern part of the state of Espírito Santo (Brazil). Na. Acad. Bras. Cien. 68(3): 389-404. 1996.

[5] Sabaini, R. S. Determinação da taxa de transporte de sedimentos na zona de espraiamento de um trecho da praia de Camburi, Vitória-ES. Master's thesis. Programa de Pós-Graduação Engenharia Ambiental. UFES. Vitória-ES, Brazil, 2008. 114p.

[6] Anjos, et. Al., Radioecology teaching: evaluation of the background radiation levels from areas with high concentrations of radionuclides in soil. Eur. J. Phys. 25 (2), 133-144. 2004.

[7] Aquino, R. R. e Pecequilo B.R.S., ${ }^{226} \mathrm{Ra},{ }^{232} \mathrm{Th}$ and ${ }^{40} \mathrm{~K}$ analysis in sand samples from some beaches. INAC 2009, 2009, Rio de Janeiro, Anais. 